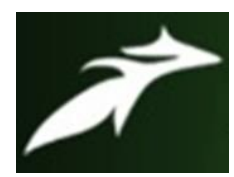

Pawan Kumar Yadav et al, International Journal of Advances in Agricultural Science \& Technology,

Vol.8 Issue.10, October-2021, pg. 39-47

\title{
Adoption Behaviour of Improved Sugarcane Cultivation Practices among the Farmers of Gonda District of Uttar Pradesh
}

\author{
Pawan Kumar Yadav*; Dr. Syed H. Mazhar**; Dr. Ms. Jahanara*** \\ *- Researcher \\ **. Advisor (Associate Professor) \\ ***- Professor\& Head
}

Department of Agricultural Extension and Communication, Sam Higginbottom University of Agriculture,

Technology and Sciences (SHUATS), Prayagraj 211007, Uttar Pradesh, India

DOI: 10.47856/ijaast.2021.v08i10.005

\begin{abstract}
The present study is an attempt to assess the socio-economic characteristics and utilization level of source of Information in improved cultivation practices of sugarcane by the farmers of Gonda District in Uttar Pradesh. Sugarcane cultivation is not prominent in this area however a large number of farmers cultivate cash crop, due to availability of information or communication channel about package of practices. Primary data from 120 respondents were collected through face to face interview. Descriptive research design had been followed for the present study. Random and Purposive sampling had been used for the present study. Farmers had a highest utilization of information by friend, neighbor and relatives $(83.34 \%)$, followed by radio i.e.75\%.Majority of $(48.33 \%)$ farmers had medium level of utilization, followed by $29.16 \%$ of farmers had high level utilization about improved cultivation practices of sugarcane.
\end{abstract}

Keywords: Knowledge, Adoption, Sources of information, sugarcane growers 


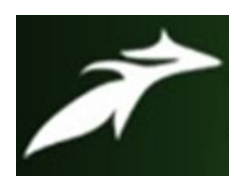

Pawan Kumar Yadav et al, International Journal of Advances in Agricultural Science \& Technology, Vol.8 Issue.10, October-2021, pg. 39-47

ISSN: 2348-1358

Impact Factor: 6.057

NAAS Rating: 3.77

\section{INTRODUCTION}

Sugarcane (Saccharum officinarum L.) is an important commercial crop of India. Sugarcane and sugar beet are used for large scale production of sugar in the world. Amongst the sugar producing plants, sugarcane is responsible for about 60 percent of world's sugar production. Sugarcane is cultivated mainly in the tropics, though in India it is also grown in sub-tropical areas.

Sugarcane is the main source of sugar in Asia and Europe. Sugarcane is grown primarily in the tropical and sub-tropical zones of the southern hemisphere. Sugarcane is the raw material for the production of white sugar, jaggery (gur) and khandsari. It is also used for chewing and extraction of juice for beverage purpose.Sugarcane is the main source of sugar in India and holds a prominent position as a cash crop. Sugarcane is one such crop as not only has a strong bearing on agro based economy of the country and industrial uses but has ample scope of improvement by way of production and productivity.

India ranks $2^{\text {nd }}$ in (area 48.67 lakh hectare), $2^{\text {nd }}$ in production (376.90million tonne) and per unit productivity (77.43tonne/ha) in year 2019-20 (Source-Sugarcane.icar.gov.in, 2020). In the world, Brazil ranks $1^{\text {st }}$ in area and production both $(99.52$ lakh hactare and 744.56 million tonnes) and Australia ranks $1^{\text {st }}$ with the per unit area productivity of 80.0 tonne/ha.

Uttar Pradesh has the largest acreage under sugarcane (21.87 lakh ha.) and accounts for about 44.93 percent of the area under this crop in 2019-20 and also accounts for 43.3 percent of the total annual production. But the production per hectare is the highest in Tamil Nadu followed by Kerala and Karnataka (Source-Sugarcane.icar.gov.in 2020).

\section{Nutritional value of Sugarcane:}

The Juice Sugarcane per serving (28.35 grams) contain Energy -111.13 KJ (26.56 Kcal), Carbohydrates-27.51 g, Protein-0.27g, Calcium-11.23mg (1\%), Iron-0.37 mg (3\%), Potassium41.96 mg (1\%), Sodium $17.01 \mathrm{mg}(1 \%)$,

Source- Directorate of Sugarcane Development Lucknow U.P. 


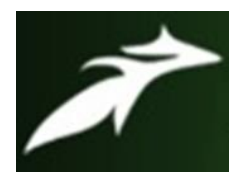

Pawan Kumar Yadav et al, International Journal of Advances in Agricultural Science \& Technology, Vol.8 Issue.10, October-2021, pg. 39-47

ISSN: 2348-1358

Impact Factor: 6.057

NAAS Rating: 3.77

\section{RESEARCH METHODOLOGY}

The study was purposively conducted in Sejhiya taluka of Gonda district in Tarabganj region of Uttar Pradesh state. Descriptive research design was used for this study. A sample of 120 sugarcane growers was down from 8 sugarcane growing villages using random sampling method. The data were collected by personal interview with the help of pretested and wellstructured interview schedule subjected to appropriate statistical analysis.

The present study has been carried out during 2020-21 in Gonda district, the district lies between 2641 to $2751^{\circ} \mathrm{N}$ latitude, 8130 to $8206^{\circ} \mathrm{E}$ longitudes. The total area of the district is $4,003 \mathrm{sq} \mathrm{km}$ out of which $925 \mathrm{sq} \mathrm{km}$ area is under cultivation. Out of 8 blocks in Gonda district, Gonda east block has been selected purposive sampling due to sugarcane is cash crop and covered higher cultivable area. In preparing the list, the help of revenuepersonal and agricultural supervisor of the concerned area were taken for authenticity and counter check of information.8 villages were purposely selected from Gonda east block, under sugarcanecultivation areas. Thereafter, the 15 farmers were selected from each village on random basis. So, the samples for the present investigation were comprised of 120 respondents. The interview schedule was developed for collection of data from the selected respondents. The general of socio-economic attributes of selected respondent'si.e.., age,education, land holding, annual income, family size, family type, sources of information, participation in extension activities were consisted as a first part of schedule. (Chouhan, 2013). In third part of schedule, appropriate statistical tools were used for data interpretation. 


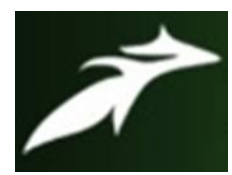

Pawan Kumar Yadav et al, International Journal of Advances in Agricultural Science \& Technology, Vol.8 Issue.10, October-2021, pg. 39-47

\section{RESULTS AND DISCUSSION}

Distribution of socio-economic attributes of the selected respondent

Table no. 1 - Distribution of respondents according to their Socio- Economic

\section{Characteristics.}

\begin{tabular}{|c|c|c|}
\hline S.NO. & CATEGORY & PERCENTAGE \\
\hline \multirow[t]{4}{*}{1.} & Age & \\
\hline & Below 36 & 30 \\
\hline & $36-55$ & 46.66 \\
\hline & Above 55 & 23.33 \\
\hline \multirow[t]{8}{*}{2} & Education & \\
\hline & Illiterate & 20 \\
\hline & Primary & 19.16 \\
\hline & Middle & 15 \\
\hline & High school & 20 \\
\hline & Intermediate & 18.34 \\
\hline & Graduate & 5.83 \\
\hline & Post graduate & 1.67 \\
\hline \multirow[t]{4}{*}{3} & Size of land holding & \\
\hline & Marginal & 30 \\
\hline & Small & 39.16 \\
\hline & Large & 30.86 \\
\hline \multirow[t]{4}{*}{4} & Annual income & \\
\hline & Low & 31.66 \\
\hline & Medium & 43.33 \\
\hline & High & 25 \\
\hline \multirow[t]{2}{*}{5} & Family Size & \\
\hline & Small size & 30 \\
\hline
\end{tabular}




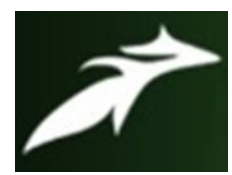

Pawan Kumar Yadav et al, International Journal of Advances in Agricultural Science \& Technology, Vol.8 Issue.10, October-2021, pg. 39-47

ISSN: 2348-1358

Impact Factor: 6.057

NAAS Rating: 3.77

\begin{tabular}{|l|l|l|}
\hline & Large size & 70 \\
\hline $\mathbf{6}$ & Family types & \\
\hline & Nuclear & 46.66 \\
\hline & Joint & 53.33 \\
\hline $\mathbf{7}$ & Sources of information & \\
\hline & Low & 31.66 \\
\hline & Medium & 48.33 \\
\hline & High & 20 \\
\hline $\mathbf{8}$ & Participation in extension activities & \\
\hline & Low & 32.50 \\
\hline & Medium & 48.33 \\
\hline & High & 19.17 \\
\hline & & \\
\hline
\end{tabular}

The socio-economic attributes of the selected respondent were given in table no.1. Majority of respondents were belonged to the age group of $36-55$ i.e. $46.66 \%$, the maximum respondents (20\%) were qualified High school. When we talk about size of land holdings then it was found through survey that $39.16 \%$ of farmers had large size of land holdings .The majority of respondents (43.33\%) had medium level of annual income i.e. 40,000-80,000. Among all the respondents, majority of respondent (70\%) belonged to large size of family. The majority of respondents $(53.33 \%)$ belonged to large types of family. The majority of respondents (53.33\%) had High level of knowledge about sources of information. And the majority of respondents were belonged to medium level of participation in extension activities. 


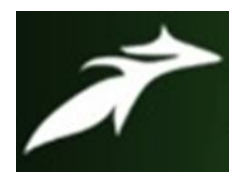

Pawan Kumar Yadav et al, International Journal of Advances in Agricultural Science \& Technology, Vol.8 Issue.10, October-2021, pg. 39-47

ISSN: 2348-1358

Impact Factor: 6.057

NAAS Rating: 3.77

\section{Utilization level of the source of Information.}

Table no. 2-Distribution of the respondents according to their source of Information.

\begin{tabular}{|c|c|c|c|c|}
\hline Sl. No. & Particulars & Frequently & Occasionally & Rarely \\
\cline { 3 - 5 } & & F (\%) & F (\%) & F (\%) \\
\hline 1. & Radio & $35(29.16)$ & $69(57.50)$ & $16(13.33)$ \\
\hline 2. & Television & $44(36.67)$ & $53(44.17)$ & $23(19.16)$ \\
\hline 3. & Newspaper & $52(43.33)$ & $36(30.00)$ & $32(26.67)$ \\
\hline 4. & Mobile & $35(29.17)$ & $52(43.33)$ & $33(27.50)$ \\
\hline 5. & Computer & $24(20.00)$ & $48(40.00)$ & $48(40.00)$ \\
\hline 6. & Internet & $52(43.34)$ & $54(45.00)$ & $14(11.66)$ \\
\hline 7. & Extension person & $28(23.34)$ & $69(57.5)$ & $23(19.16)$ \\
\hline 8. & NGO & $23(19.17)$ & $65(54.17)$ & $32(26.66)$ \\
\hline 9. & Any other & $13(10.83)$ & $69(57.50)$ & $38(31.66)$ \\
\hline
\end{tabular}

\begin{tabular}{|c|c|c|c|}
\hline S. No. & Category & Frequency & Percentage \\
\hline $\mathbf{1}$ & Low (9-14) & 38 & 31.66 \\
\hline $\mathbf{2}$ & Medium (15-21) & 58 & 48.33 \\
\hline $\mathbf{3}$ & High (22-27) & 24 & 20.00 \\
\hline & Total & $\mathbf{1 2 0}$ & $\mathbf{1 0 0 . 0 0}$ \\
\hline
\end{tabular}

9 source of Information used by the respondents to seek information about improved cultivation practices were identified in this study. Pattern of use of source of Information can be helpful in diffusing agricultural information among them effectively. For this purpose, data regarding extent use of source of Information by sugarcane grower were collected. 


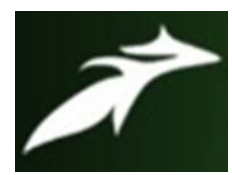

Pawan Kumar Yadav et al, International Journal of Advances in Agricultural Science \& Technology, Vol.8 Issue.10, October-2021, pg. 39-47

ISSN: 2348-1358

Impact Factor: 6.057

NAAS Rating: 3.77

Table 3: Distribution of respondents on the basis of knowledge Level.

\begin{tabular}{|l|l|l|}
\hline Knowledge Level & Frequency & Total percent \\
\hline Low (Below 70) & 21 & 17.50 \\
\hline Medium (70 to 80) & 76 & 63.33 \\
\hline High (Above 80) & 23 & 19.66 \\
\hline Total & $\mathbf{1 2 0}$ & $\mathbf{1 0 0 . 0 0}$ \\
\hline
\end{tabular}

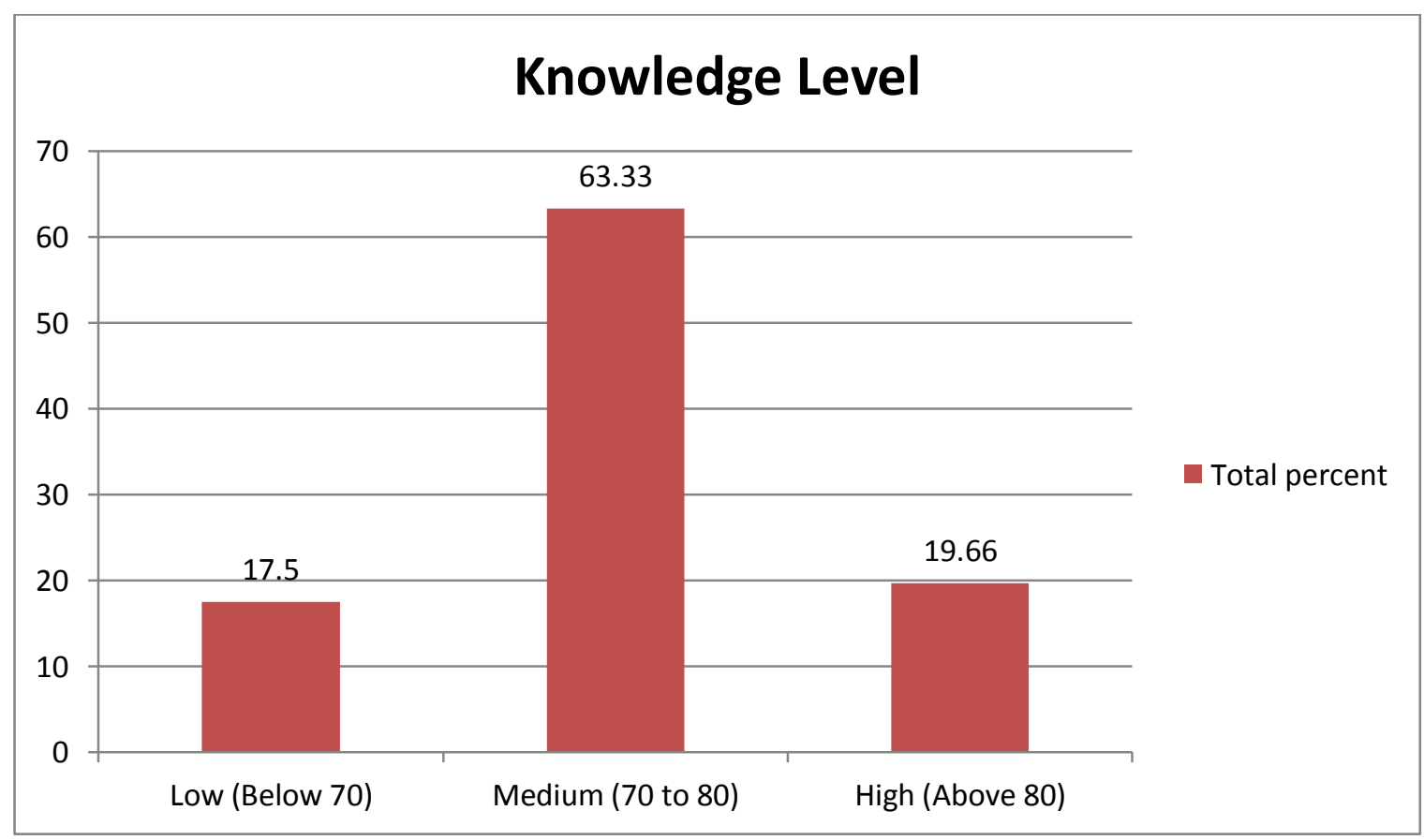

Figure 1: Distribution of respondents on the basis of knowledge Level.

In table no. 3 and fig. 1 it is evident that majority of respondents had medium level $63.33 \%$ of the knowledge level, while $19.66 \%$ of respondents had high level of knowledge and $17.50 \%$ of the respondents had low level of knowledge level. 


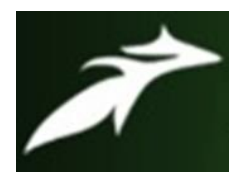

Pawan Kumar Yadav et al, International Journal of Advances in Agricultural Science \& Technology, Vol.8 Issue.10, October-2021, pg. 39-47

ISSN: 2348-1358

Impact Factor: 6.057

NAAS Rating: 3.77

Table no. 4 - Distribution of respondents on the basis of their adoption Level.

\begin{tabular}{|l|l|l|}
\hline S.NO. & \multicolumn{1}{|c|}{ CATEGORY } & PERCENTAGE \\
\hline 1 & Low & 15.84 \\
\hline 2 & Medium & 60.00 \\
\hline 3 & High & 24.16 \\
\hline
\end{tabular}

Figure no. 2 - Distribution of respondents according to their Adoption Level.

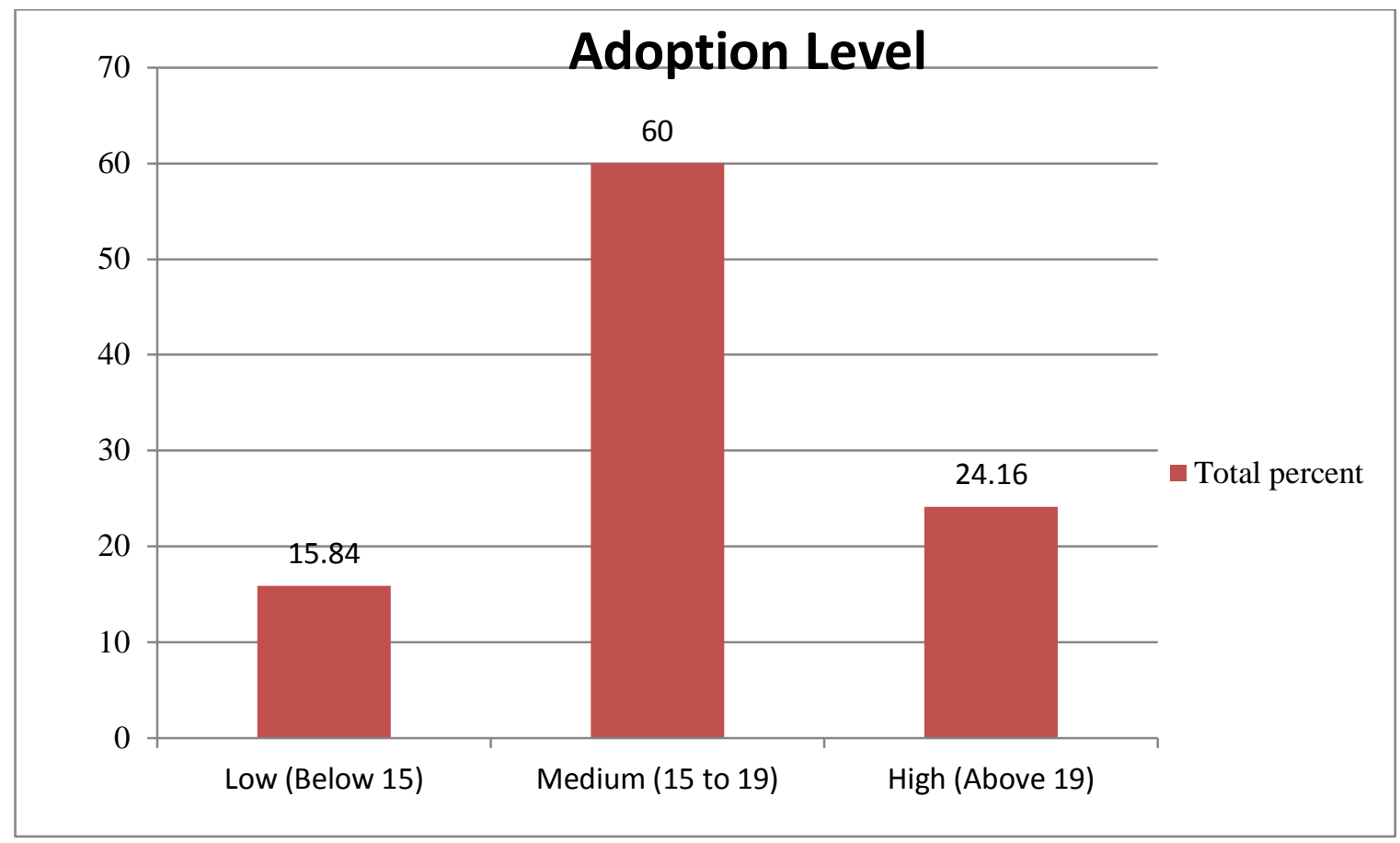

In table no. 4 and fig. 2 it is evident that majority of respondents had medium level $60 \%$ of the adoption level, while $24.16 \%$ of respondents had high level of adoption and $15.84 \%$ of the respondents had low level of adoption level. 


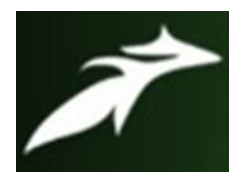

Pawan Kumar Yadav et al, International Journal of Advances in Agricultural Science \& Technology, Vol.8 Issue.10, October-2021, pg. 39-47

ISSN: 2348-1358

Impact Factor: 6.057

NAAS Rating: 3.77

\section{CONCLUSION}

It is concluded that majority of the respondents were middle age group had large size of land holding. Majority of respondents were qualified more than high school level. Maximum number of respondents had medium level of income. Majority of respondentspossess high level of source of information. And majority of respondents had medium level of adoption of improved cultivation practices of sugarcane. Reason behind the majority of respondent having medium level of utilization is that majority of respondents were of middle age group and people of this age in rural areas are not so fluent in using smartphones, maximum respondents had educational qualification only up to $10^{\text {th }}$, lack of technical knowledge and unavailability of print materials are some reason behind medium level of utilization

\section{REFERENCES}

[1]. Chouhan Sandeep, Singh, S.R.K., Pande, A.K. and Gautam, U.S. (2013).Adoption dynamics of improved sugarcane cultivation in Madhya Pradesh. Indian Research Journal of Extension Education 13 (2):26-30.

[2]. Kumar, A.; Jahanara and Bose, D.K.; (2018).Knowledge and attitude of the respondents towards sugarcane cultivation practices in Khumbi Block of Lakhimpur Kheri District of Uttar Pradesh. International Journal of Research Culture Society. 2 (1):399-402

[3]. Patel, G.G., Bafna, A. M. and Das, A. (2011).Effect of integrated nutrient management on fresh yield and uptake of sugarcane plant and ratoon crops and soil properties in Vertic Ustochrept of South Gujrat. Indian Sugar. 61(4): 31-43.

[4]. Rathod, G.V., Salame, S.P., and Deokate, N. (2018).Knowledge and adoption of improved cultivation practices by sugarcane growers. International Journal of Chemical Studies. 6(6): 653-654.

[5]. Singh, S.P.; Singh H.P., Kumari, M. and Meena, L. (2018), Assessment of variations in yield gap and constraints analysis in the sugarcane production in Bihar. International Journal of Current Microbiology and Applied Sciences 6(7):2667-2675. 